\title{
IDENTIFIKASI DAN PEMETAAN MORFOMETRI DAERAH ALIRAN SUNGAI MARTAPURA MENGGUNAKAN TEKNOLOGI GIS
}

\author{
Ferry Sobatnu', Faris Ade Irawan', Agus Salim ${ }^{2}$ \\ (1) Dosen Jurusan Teknik Sipil Politeknik Negeri Banjarmasin \\ (2) Praktisi Teknik Sipil \\ ${ }^{1}$ sobatnu@poliban.ac.id (corresponding author); faris.irawan@poliban.ac.id
}

\begin{abstract}
ABSTRAK
Rendahnya letak daratan Kabupaten Banjar dari permukaan laut menyebabkan aliran air pada permukaan tanah menjadi kurang lancar. Akibatnya sebagian wilayah selalu tergenang mencapai 29,93\%, sebagian lagi 0,58\% tergenang secara periodik. Hampir setiap tahun saat musim hujan tiba dengan intensitas yang tinggi di wilayah Martapura terjadi banjir dengan ketinggian hingga \pm 1 meter. Berdasarkan data Badan Penanggulangan Bencana Daerah (BPBD), ada delapan kecamatan yang rawan dilanda banjir. Yaitu Kecamatan Sungai Pinang, Sambung Makmur, Pengaron, Astambul, Karang Intan, Martapura, Sungai Tabuk, dan Mataraman. Penelitian dilakukan dengan bantuan peranti lunak Arcgis menggunakan alat calculate geometry untuk mengidentifikasi Morfometri. Morfometri DAS merupakan ukuran kuantitatif karakteristik DAS yang terkait dengan aspek geomorfologi suatu daerah. Karakteristik ini terkait dengan proses drainase air hujan yang jatuh di dalam DAS. Hasil penelitian menujukan DAS Martapura mempunyai luas 453,88 $\mathrm{km}^{2}$, panjang sungai utama mencapai 36.566 meter, kemiringan (gradien) sebesar $0.022 \%$. Tingkat kerapatan sungai yaitu $0,828 \mathrm{~km} / \mathrm{km}^{2}$. Tingkatan orde sungai mencapai 10 orde. Pola sungai adalah rektangular dengan jenis DAS yang berbentuk paralel. Berdasarkan data pemetaan dan identifikasi mengenai daerah aliran sungai (DAS) Martapura ini, sehingga dapat dihasilkan informasi penting. Informasi Morfometri DAS tersebut bisa dijadikan referensi untuk pemecahan masalah lingkungan dan manajemen Daerah Aliran Sungai.
\end{abstract}

Kata Kunci - Morfometri, DAS Martapura, Arcgis

\section{ABSTRACT}

The low location of the Banjar district land from the sea surface causes the flow of water on the soil surface becomes substandard. Consequently some areas always stagnant to reach $29.93 \%$, some $0.58 \%$ flooded periodically. Almost every year when the rainy season arrives with a high intensity in the Martapura area there is a flood with an altitude of up to \pm 1 meter. Based on data of regional disaster management agency (BPBD), there are eight districts that are prone to flooding. Namely, Sungai Pinang district, Sambung Makmur, Pengaron, Astambul, Karang Intan, Martapura, Sungai Tabuk, dan Mataraman. Research was conducted with the help of Arcgis software using a calculate geometry tool to identify morphometry. Watershed morphometry is a quantitative measure of watershed characteristics associated with the geomorphological aspects of a region. These characteristics are related to the rainwater drainage process that falls within the watershed. The research results show watershed Martapura has an area of $453.88 \mathrm{~km}^{2}$, the length of the main river reaches 36,566 meters, the slope (gradient) of $0.022 \%$. River density level is $0.828 \mathrm{~km} / \mathrm{km}^{2}$. The order level of the river reaches 10 level. The pattern of the river is rektangular with the type of watershed in parallel. Based on data mapping and identification of Martapura river basin, so that important. information can be generated. such morphometric data can be used as reference for environmental problem solving and watershed management.

Keywords - Morphometry, Watershed Martapura, Arcgis 


\section{PENDAHULUAN}

Morfometri DAS merupakan ukuran kuantitatif karakteristik DAS yang terkait dengan aspek geomorfologi suatu daerah. Karakteristik ini terkait dengan proses (drainase) air hujan yang jatuh di dalam DAS. Parameter tersebut adalah luas DAS, bentuk DAS, jaringan sungai, kerapatan aliran, pola aliran, dan gradien kecuraman sungai. Kalimantan Selatan mempunyai Daerah Aliran Sungai (DAS) yang sangat luas, dan dalam pengelolaannya diperlukan suatu informasi untuk mendukung prosedur teknis sebagai upaya untuk memaksimalkan fungsi DAS itu sendiri. Serta disamping itu juga sistem informasi dari DAS itu sendiri berguna untuk analisis bahaya banjir, degradasi sungai, dan sebagainya. Sebagai contoh kasus pada Kota Martapura dengan DAS nya yaitu DAS Martapura

Kabupaten Banjar yang terletak antara $2^{\circ} 49^{\prime} 55^{\prime \prime}$ $3^{\circ} 43^{\prime} 38^{\prime}$ " pada garis Lintang Selatan dan $0^{\circ} 35^{\prime} 37^{\prime}$ - $114^{\circ}$ 30'20" hingga 115 pada Bujur Timur, dan terbagi menjadi 19 kecamatan, dengan 290 desa/ kelurahan.

Ketinggian wilayah kabupaten ini berkisar antara 0-1.878 meter dari permukaan laut (dpl). Ketinggian ini merupakan salah satu faktor yang menentukan letak kegiatan penduduk, Ketinggian juga dipakai sebagai penentuan batas wilayah tanah usaha, dimana $35 \%$ berada di ketinggian 0-7 m dpl, 55,54\% ada pada ketinggian 50-300 m dpl, sisanya 9,45\% lebih dari $300 \mathrm{~m} \mathrm{dpl}$.

Rendahnya letak Kabupaten Banjar dari permukaan laut menyebabkan aliran air pada permukaan tanah menjadi kurang lancar. Akibatnya sebagian wilayah selalu tergenang (29,93\%) sebagian lagi $(0,58 \%)$ tergenang secara periodik. Pada umumnya tanah di wilayah ini bertekstur halus $(77,62 \%)$ yaitu meliputi tanah liat, berlempung, ber-pasir dan berdebu Sementara $14,93 \%$ bertekstur sedang yaitu jenis lempung, berdebu, liat berpasir, sisanya 5,39 \% bertekstur kasar yaitu pasir berlempung, pasir berdebu.

Hampir setiap tahun saat musim hujan tiba dengan intensitas yang tinggi di Martapura terjadi banjir dengan ketinggian hingga \pm 1 meter. Berdasarkan data Badan Penanggulangan Bencana Daerah (BPBD) ada delapan kecamatan yang rawan dilanda banjir. Yaitu Kecamatan Sungai Pinang, Sambung Makmur, Pengaron, Astambul, Karang Intan, Martapura, Sungai Tabuk, dan Mataraman. Berdasarkan hal itulah dibutuhkan identifikasi mengenai DAS Martapura tersebut, sehingga dapat dihasilkan informasi, dalam hal ini adalah Morfometri DAS untuk DAS Martapura. Informasi morfometri DAS tersebut bisa dijadikan referensi untuk pemecahan masalah lingkungan dan untuk perencanaan pengolahan DAS.

Tujuan penelitian adalah membuat peta dan mengidentifikasi Morfometri Daerah Aliran Sungai Martapura. Peta dan hasil identifikasi dapat dijadikan referensi untuk pengawasan keadaan sungai dan perencanaan suatu pengelolaan DAS, sehingga dapat diambil keputusan yang tepat bila terjadi permasalahan sungai.

\section{KAJIAN PUSTAKA}

\section{A. Daerah Aliran Sungai (DAS)}

Daerah Aliran Sungai (DAS)/Daerah Pengaliran Sungai (DPS) atau drainage basin adalah suatu daerah yang terhampar di sisi kiri dan kanan dari suatu aliran sungai, dimana semua anak sungai yang terdapat di sebelah kanan dan kiri sungai bermuara ke dalam suatu sungai induk. Seluruh hujan yang terjadi didalam suatu drainage basin, semua airnya akan mengisi sungai yang terdapat di dalam DAS tersebut. Oleh sebab itu, areal DAS juga merupakan daerah tangkapan hujan atau disebut catcment area. Semua air yang mengalir melalui sungai bergerak meninggalkan daerah tangkapan sungai dengan atau tampa memperhitungkan jalan yang ditempuh sebelum mencapai limpasan (run off). (Mulyo, 2004).

\section{B. Morfometri}

Morfometri merupakan ukuran kuantitatif karakteristik yang terkait dengan aspek geomorfologi suatu daerah. Morfomeri Daerah Aliran Sungai adalah istilah yang digunakan untuk menyatakan keadaan jaringan alur sungai secara kuantitatif. Karakteristik ini terkait dengan proses pengatusan drainase air hujan yang jatuh di dalam DAS. Parameter keadaan yang dimaksud untuk analisa aliran sungai antara lain meliputi;

\section{Luas DAS}

DAS merupakan tempat pengumpulan presipitasi ke suatu sistem sungai. Luas daerah aliran dapat diperkirakan dengan mengukur daerah tersebut pada peta topografi. Garis batas antara DAS adalah punggung permukaan bumi yang dapat memisahkan dan membagi air hujan ke masing-masing DAS. Garis batas tersebut ditentukan berdasarkan perubahan kontur dari peta tofografi, sedangkan luas DAS nya dapat diukur dengan alat planimeter. Skala peta yang digunakan akan mempengaruhi ketelitian perhitungan luasnya. Adapun formula untuk perhitungan luas yaitu:

$$
\text { Luas }=\text { Jumlah kotak } x \text { (skala)2 }
$$

\section{Panjang dan lebar}

Panjang DAS adalah sama dengan jarak datar dari muara sungai ke arah hulu sepanjang sungai induk. Sedangkan lebar DAS adalah perbandingan antara luas DAS dengan panjang sungai induk.

\section{Lebar $=$ Luas DAS/Panjang Sungai Induk}




\section{Kemiringan atau Gradien Sungai}

Gradien atau kemiringan sungai dapat diperoleh dengan persamaan sebagai berikut:

$$
\text { G = Jarak Vertikal/Jarak Horisontal }
$$

$$
\begin{array}{ll}
\text { Keteranga: } & =\text { Gradien Sungai } \\
\mathrm{G} & =\text { Beda tinggi antara hulu dengan hilir }(\mathrm{m}) \\
\mathrm{J} \text {. Vertikal } & =\text { Panjang sungai induk }(\mathrm{m})
\end{array}
$$

\section{Orde Sungai}

Alur sungai dalam suatu DAS dapat dibagi dalam beberapa orde sungai. Orde sungai adalah posisi percabangan alur sungai di dalam urutannya terhadap induk sungai di dalam suatu DAS. Dengan demikian makin banyak jumlah orde sungai akan semakin luas pula DAS nya dan akan semakin panjang pula alur sungainya. Tingkat percabangan sungai (bifurcation ratio) adalah angka atau indeks yang ditentukan berdasarkan jumlah alur sungai untuk suatu orde.

\section{Tingkat Percabangan Sungai}

Untuk menghitung tingkat percabangan sungai dapat digunakan rumus:

$$
\mathbf{R b}=\mathbf{N u} / \mathbf{N u}+\mathbf{1}
$$

Keterangan:

$\mathrm{Rb}=$ Indeks tingkat percabangan sungai

$\mathrm{Nu}=$ jumlah alur sungai untuk orde ke $\mathrm{u}$

$\mathrm{Nu}+1=$ jumlah alur sungai untuk orde ke $\mathrm{u}+1$

\section{Kerapatan Sungai}

Kerapatan sungai adalah suatu angka indeks yang menunjukkan banyaknya anak sungai di dalam suatu DAS. Indeks tersebut diperoleh dengan persamaan sebagai berikut:

$$
\mathbf{D d}=\mathbf{L} / \mathbf{A}
$$

Keterangan:

$\mathrm{Dd}=$ indeks kerapatan sungai $(\mathrm{km} / \mathrm{km} 2)$

$\mathrm{L}=$ jumlah panjang sungai termasuk anak-anak sungainya $\left(\mathrm{km}^{2}\right)$

$\mathrm{A}=$ Luas DAS $\left(\mathrm{km}^{2}\right)$

TABEL I

Parameter Tingkat Kerapatan Sungai

\begin{tabular}{|c|c|c|l|}
\hline No & $\begin{array}{c}\text { Dd } \\
\left(\mathrm{km} / \mathrm{km}^{2}\right)\end{array}$ & $\begin{array}{c}\text { Kelas } \\
\text { Kerapatan }\end{array}$ & \multicolumn{1}{c|}{ Keterangan } \\
\hline 1 & $<0.25$ & Rendah & $\begin{array}{l}\text { Alur sungai melewati Batuan dengan resestensitas keras. } \\
\text { maka angkutan sedemen yang terangkut aliran sungai lebih } \\
\text { kecil jika di bandingkan pada alur sungai yang melewati } \\
\text { batuan dengan resistensitas yang lebih lunak, apabila } \\
\text { kondisi lain yang mempengaruhi sama. }\end{array}$ \\
\hline 2 & $<0.25-10$ & Sedang & $\begin{array}{l}\text { Alur sungai melewati batuan dengan resestensi yang lebih } \\
\text { lunak, sehingga angkutan sedimen yang tersangkut aliran } \\
\text { akan lebih besar. }\end{array}$ \\
\hline 3 & $10-25$ & Tinggi & $\begin{array}{l}\text { Alur sungai melewati batuan dengan resestensi yang lunak, } \\
\text { sehingga angkutan sedimen yang terangkut akan lebih } \\
\text { besar. }\end{array}$ \\
\hline 4 & $<25$ & Sangat tinggi & $\begin{array}{l}\text { Alur sungai melewati batuan yang kedap air. Keadaan ini } \\
\text { akan menunjukan bahwa air hujan yang menjadi aliran } \\
\text { akan lebih besar jika dibandingkan dengan suatu daerah Dd } \\
\text { rendah melewati batuan yang permebilitas besar. }\end{array}$ \\
\hline
\end{tabular}

(Sumber: soewarno, 1991)

\section{Bentuk Daerah Aliran Sungai}

Pola sungai menentukan bentuk suatu DAS. Bentuk DAS mempunyai arti penting dalam hubungannya dengan aliran sungai, yaitu berpengaruh terhadap kecepatan terpusat aliran.

Menurut Gregari dan Walling (1975), untuk menentukan bentuk DAS dapat diketahui dengan terlebih dahulu menentukan nilai Rc nya.

$$
R c=\frac{4 n A}{P 2}
$$

Keterangan:

$\mathrm{Rc}=$ Basin circularity.

$\mathrm{A}=\operatorname{Luas} \mathrm{DAS}\left(\mathrm{m}^{2}\right)$

$\mathrm{P}=$ Keliling $(\mathrm{m})$

$\Pi=3,14$

\section{Geographics Information System (GIS)}

GIS atau SIG adalah sebuah system yang terdiri dari perangkat keras, perangkat lunak, data, manusia, organisasi dan lembaga yang digunakan untuk mengumpulkan, menyimpan dan menganalisa, menyebarkan informasiinformasi mengenai daerah-daerah dipermukaan bumi. Dalam arti luas, Sistem Informasi Geografis merupakan suatu sistem yang berbasiskan komputer yang digunakan untuk memanipulasi data secara geografis dan selanjutnya dapat dipakai sebagai bahan acuan dalam pengambilan keputusan. SIG juga digunakan untuk mengumpulkan, menyimpan dan menganalisa objek atau fenomena lain dimana lokasi geografis merupakan karakteristik yang sangat penting dalam proses menganalisa. Dapat disimpulkan bahwa SIG merupakan suatu alat, metode dan prosedur yang mempermudah dan mempercepat usaha untuk menemukan dan memahami persamaan-persamaan dan perbedaan-perbedaan yang ada dalam ruang muka bumi. (Prahasta, Eddy. 2009).

Pada dasarnya istilah sistem informasi geografis merupakan gabungan dari tiga unsur pokok : sistem, informasi dan geografis. Jadi sistem informasi geografis adalah kumpulan dari sistem yang terorganisir dari perangkat keras komputer, perangkat lunak, dan data geografi yang dirancang secara efisien untuk memperoleh, menyimpan, meng-update, memanipulasi, meganalisis dan menampilkan semua bentuk informasi dan data yang bereferensi geografi. Oleh sebab itu dari definisi tersebut maka sistem informasi geografis memiliki kemampuan-kemampuan yaitu :

1. Memasukkan dan mengumpulkan data geografi (spasial dan attribut).

2. Mengintergrasikan data geografi (spasial dan atribut).

3. Memeriksa, meng-update (mengedit), data geografis (spasial dan attribut).

4. Menyimpan dan memanggil kembali data geografi (spasial dan attribut). 
5. Mempresentasikan atau menampilkan data geografi (spasial dan attribut).

6. Mengelola data, memanipulasi data geografi (spasial dan attribut).

7. Menghasilkan keluaran (output) data geografi dalam bentuk-bentuk peta tematik, tebal dan data atribut/tabular.

\section{Perangkat ArcGIS}

ArcGIS adalah salah satu perangkat lunak SIG yang memiliki versi desktop. Perangkat lunak ini memiliki banyak fungsional, exstension yang sudah terintegrasi, dan juga mengimplementasikan konsep basis data spasial; khususnya geodatabase (baik personal maupun multi-user). ArcGIS dibuat untuk performance GIS yang tinggi contoh untuk Web GIS, Server GIS, Database GIS yang besar, dsb. Kelemahan ArcGIS adalah programnya relatif besar (1,5 gigabyte), dan membutuhkan spesifikasi komputer yang tinggi RAM minimal 256 mega, VGA 128 Mega, processor Pentium IV dan sekelasnya hardisk 40 GB. (Prahasta, Eddy. 2009).

1. ArcReader, yang memungkinkan seseorang untuk melihat peta dan query yang dibuat dengan produk Arc lainnya;

2. ArcView, yang memungkinkan seseorang untuk melihat data spasial, membuat berlapis peta, dan melakukan dasar analisis spasial;

3. ArcEditor, yang disamping fungsi ArcView, termasuk alat yang lebih canggih ntuk manipulasi shapefile dan geodatabases;

4. ArcInfo, ang mencakup kemampuan untuk manipulasi data, mengedit, dan analisis.

5. Ada juga berbasis server ArcGIS produk, serta produk ArcGIS untuk PDA. Ekstensi dapat dibeli secara terpisah untuk meningkatkan fungsi ArcGIS.

\section{E. Perangkat Global Mapper}

Global Mapper adalah salah satu perangkat lunak yang cukup populer sering digunakan oleh kalangan praktisi GIS (geographics information system) atau orang-orang yang berkecimpung di bidang pemetaan. Salah satu keistimewaan program ini adalah kompatibilitasnya dengan banyak sekali format file. Sehingga dapat digunakan oleh banyak orang dari latar belakang pengetahuan perangkat lunak lain yang berbedabeda. Global Mapper dari Intermap lebih dari sekadar alat penayang yang menampilkan arsiran, elevasi, atau kumpulan data vektor yang paling populer: Perangkat ini juga dapat mengkonversi, mengedit, mencetak, melacak GPS, dan memungkinkan Anda menerapkan fungsi SIG pada kumpulan data Anda dalam satu paket perangkat lunak berbiaya rendah dan mudah digunakan. Keuntungan Global Mapper:
1. Melakukan perhitungan jarak dan luas dengan akurat, pembauran arsir dan penyesuaian kontras, melihat elevasi, dan perhitungan garis pandang untuk memaksimalkan presisi.

2. Secara rutin menghemat waktu yang dihabiskan untuk melakukan tugas berulang dengan menggunakan fungsi bahasa script yang built-in dan konversi batch secara menyeluruh.

3. Dengan cepat mendigitalkan fitur vektor baru, mengedit fitur yang sudah ada, dan dengan mudah menyimpannya ke format ekspor yang didukung.

4. Dengan mudah melacak setiap perangkat GPS yang kompatibel yang terhubung ke port serial komputer Anda melalui data apa pun yang di-upload, menandai waypoint tanpa sambungan, serta merekam log pelacakan.

5. Dalam sekejap menetapkan interval kontur untuk setiap kombinasi data elevasi dengan fitur pembuat kontur tingkat lanjut.

6. Secara otomatis melakukan triangulasi dan grid kumpulan data titik 3D untuk mengkonversi contoh kumpulan elevasi menjadi kumpulan data yang sepenuhnya di-grid.

7. Dengan cepat menyimpan isi layar menjadi file BMP, JPG, PNG, atau (Geo) TIFF, yang dapat Anda rektifikasi secara intuitif dan disimpan dalam citra baru yang sepenuhnya dapat dijadikan georeferensi.

8. Dengan segera melakukan dekompresi setiap transfer file SDTS ke direktori yang terpisah, menghemat waktu yang berharga.

9. Segera menampilkan file DRG terdekat melalui kliping otomatis file collar USGS DRG

\section{METODE PENELITIAN}

1. Penyediaan perangkat penelitian, terdiri dari:

a. Penyiapan perangkat keras komputer;

- Komputer

- Mouse

- Printer

b. Penyediaan perangkat lunak komputer;

- Arc Gis 10.3

- Global Mapper 15

- Microsof word 2010

c. Bahan sebagai data meliputi;

- Peta DAS Barito

- DEM Kalimantan Selatan (Open Source Online)

- Peta Sungai dalam DAS Martapura (Bakosurtanal)

- Shapefile sungai utama.

2. Sistematika penelitian 
Sistematika pelaksanaan kerja dapat dilihat pada gambar 1 diagram alir sebagai berikut.

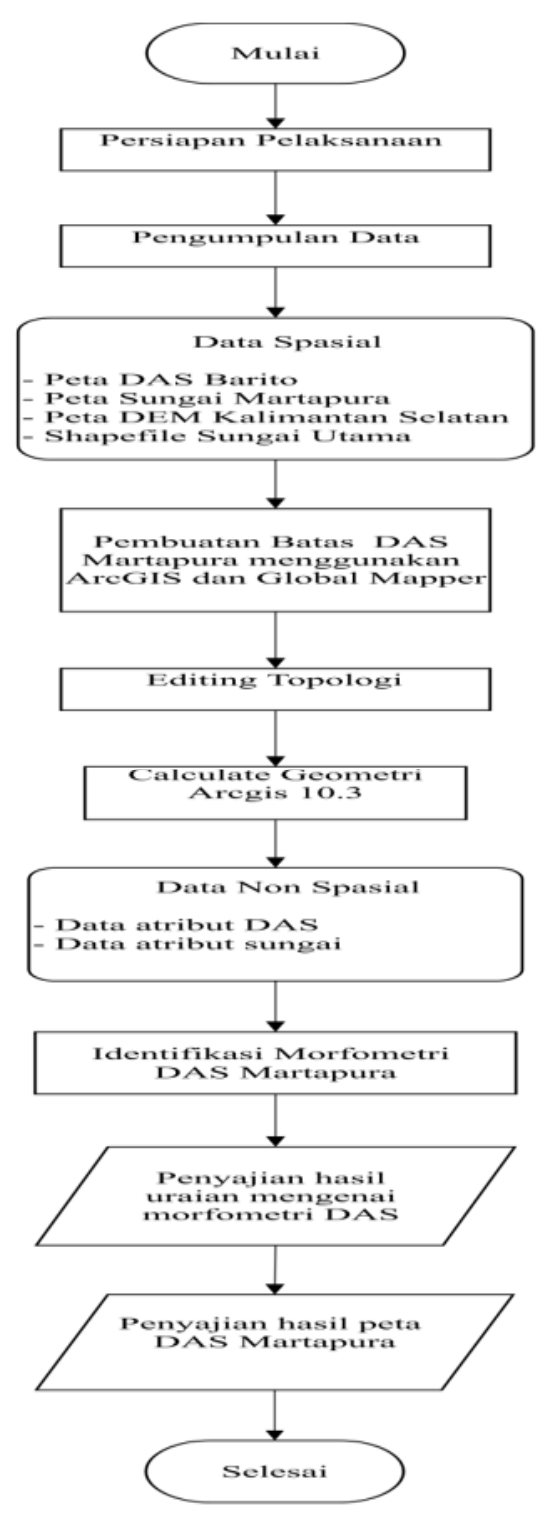

Gambar 1. Sistematik Pelaksanaan Kerja

\section{PEMBAHASAN DAN HASIL}

\section{A. Analisis Kritis Data Spasial}

Pembuatan batas DAS dilakukan dengan proses dalam ArcGIS menggunakan peta DEM Kal-Sel. Namun karena peta dalam luasan Kal-Sel, maka DEM harus di potong terlebih dahulu dan disesuaikan dengan peta DAS Barito. Pemotongan DEM sendiri menggunakan aplikasi Global Mapper, data yang ditumpang susun (Overlay) yaitu, data DEM Kal-Sel dan batas DAS Barito.
1) DEM (Digital Elevation Model) Kalimantan Selatan pada gambar 2 sebagai data dasar. DEM digunakan untuk membuat batas DAS Martapura dengan melihat kondisi topografi nya, DEM dibutuhkan saat proses di ArcGIS maupun Global Mapper.

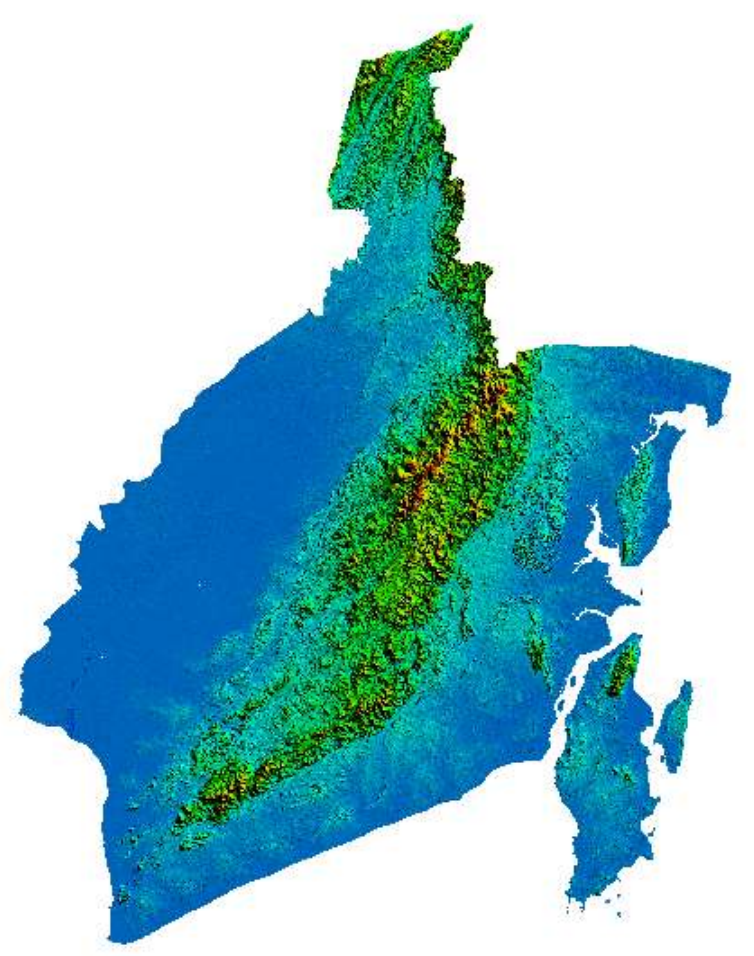

Gambar 2. DEM Kalimantan Selatan

2) Tampilan Shapefile peta jaringan sungai dalam cakupan DAS Barito pada gambar 3 yang menjadi data dasar spasial peta jaringan DAS Barito untuk membuat DAS Martapura.

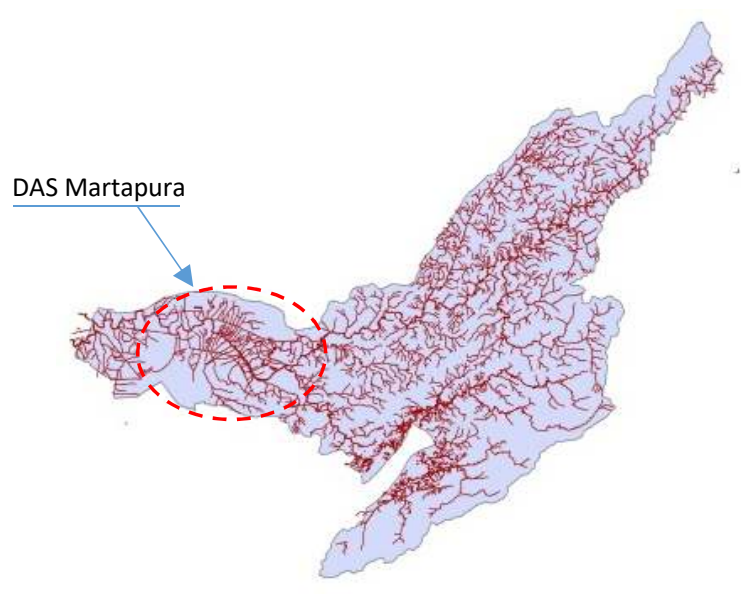

Gambar 3. Shapefile Jaringan Sungai DAS Barito 
Setelah DEM sudah dipotong maka pembuatan batas DAS Martapura bisa dimulai. Pembuatan batas DAS Martapura sendiri dilakukan dengan 2 tahap, yaitu tahap pertama proses di ArcGIS secara otomatis, dan tahap kedua secara manual di Global Mapper.

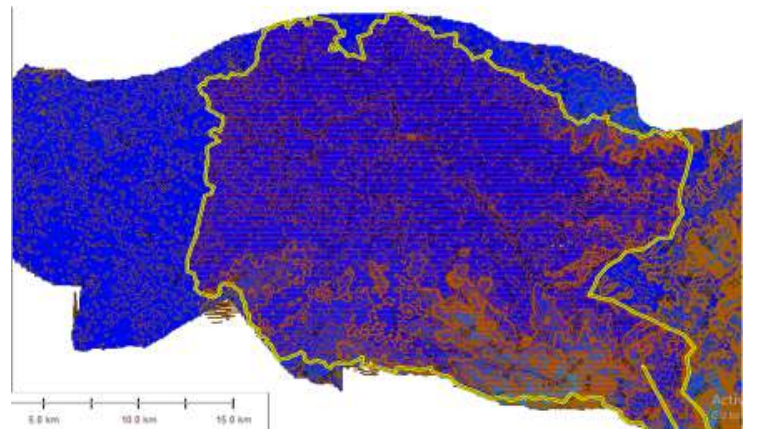

Gambar 4. Pembuatan garis batas DAS

3) Gambar 4 adalah tampilan peta DAS Martapura hasil analisis spasial.

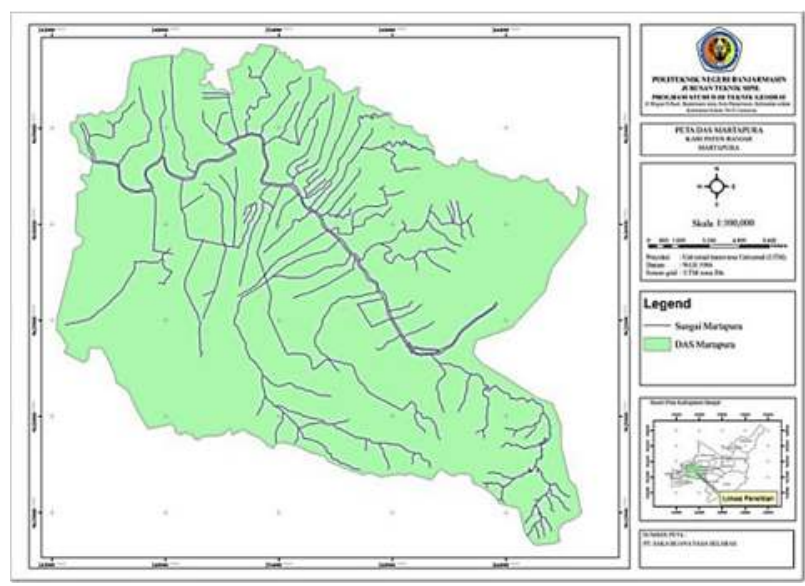

Gambar 5. DAS Martapura

4) Menghitung data atribut DAS Martapura menggunakan perintah Calculate Geometry di perangkat ArcGIS menghasilkan informasi seperti pada Tabel I dan II.

TABEL I

Atribut Luas DAS Martapura.

\begin{tabular}{|c|c|c|c|c|}
\hline \multicolumn{5}{|c|}{ DAS_Martapura } \\
\hline FID & Shape ${ }^{*}$ & NAME & luas & Keliling \\
\hline 0 & Polygon & DAS Martapura & 453.887905 & 116.524653 \\
\hline
\end{tabular}

(sumber: Hasil Analisis Laboratorium PJ dan SIG Politeknik Negeri Banjarmasin)
TABEL II

Atribut Panjang dan Orde DAS Martapura.

\begin{tabular}{|c|c|c|c|c|c|}
\hline FID & Shape * & Entity & Layer & Length & Orde \\
\hline 0 & Polyline & Polyline & SUNGAI_SH & 1201.201 & 1 \\
\hline 1 & Polyline & Polyline & SUNGAI_SH & 1755.999 & 1 \\
\hline 2 & Polyline & Polyine & SUNGAI_SH & 4605.751 & 2 \\
\hline 3 & Polyline & Polyline & SUNGAI_SH & 4205.503 & 1 \\
\hline 4 & Polyline & Polyline & SUNGAI_SH & 1366.499 & 1 \\
\hline 5 & Polyline & Polyine & SUNGAI_SH & 2375.206 & 2 \\
\hline 6 & Polyline & Polyline & SUNGAI_SH & 1356.437 & 1 \\
\hline 7 & Polyline & Polyline & SUNGAI_SH & 6578.303 & 1 \\
\hline 8 & Polyline & Polyine & SUNGAI_SH & 3562.284 & 1 \\
\hline 9 & Polyline & Polyline & SUNGAI_SH & 5352.662 & 1 \\
\hline 10 & Polyline & Polyline & SUNGAI_SH & 1861.437 & 1 \\
\hline 11 & Polyline & Polyline & SUNGAI_SH & 5298.441 & 1 \\
\hline 12 & Polyline & Polyline & SUNGAI_SH & 460.1733 & 1 \\
\hline 13 & Polyline & Polyine & SUNGAI_SH & 7803.114 & 1 \\
\hline 14 & Polyline & Polyline & SUNGAI_SH & 1530.017 & 1 \\
\hline 15 & Polyline & Polyline & SUNGAI_SH & 1591.162 & 1 \\
\hline 16 & Polyline & Polyline & SUNGAI_SH & 2145.891 & 1 \\
\hline 17 & Polyline & Polyline & SUNGAI_SH & 1843.197 & 2 \\
\hline 18 & Polyline & Polyline & SUNGAI_SH & 841.6143 & 2 \\
\hline 19 & Polyline & Polyline & SUNGAI_SH & 3667.445 & 1 \\
\hline 20 & Polyline & Polyline & SUNGAI_SH & 3232.477 & 1 \\
\hline 21 & Polyline & Polyline & SUNGAI_SH & 2094.026 & 2 \\
\hline
\end{tabular}

(sumber: Hasil Analisis Laboratorium PJ dan SIG Politeknik Negeri Banjarmasin)

\section{B. Verifikasi Lapangan}

Survei pengambilan koordinat referensi di lapangan dilakukan dengan menentukan empat titik pengamatan menggunakan alat GPS (Global Positioning System). Tahapan ini harus dilakukan sebagai acuan dalam kalibrasi dan memvalidasi nilai ketinggian yang di tunjukkan oleh kontur pada DEM. Proses tersebut di lakukan di ArcGIS dengan memasukan nilai koordinat hasil survei menggunakan perintah georeferencing. Hasil georeferencing terhadap empat titik koordinat tersebut menunjukkan nilai RMS error $<1$. Setelah proses ini dilakukan barulah tahapan identifikasi morfometri dapat dilaksanakan.

\section{Identifikasi Morfometri DAS Martapura}

Hasil identifikasi Morfometri DAS Martapura Meliputi:

1. DAS Martapura adalah sub-DAS dari DAS Barito yang merupakan bagian dari WS (Wilayah Sungai) Barito. DAS Martapura yang sungai utama nya dikenal dengan sungai Riam Kanan melewati kota Martapura dan mempunyai daerah hulu yaitu Bendungan Riam Kanan. DAS Martapura mempunyai luas $453,88 \mathrm{~km}^{2}$ atau 45.388 hektar.

2. Panjang sungai utama $36.566 \mathrm{~m}$. Berdasarkan analisis DEM Kalimantan Selatan, diperoleh nilai elevasi daerah Hulu mencapai 14 meter dan Hilir mencapai 6 meter, maka 
di dapat beda tinggi dari Hulu ke Hilir adalah 8,00 m, sehingga gradien bisa dihitung.

$$
\begin{array}{ll}
\text { Jarak vertikal } & =8,00 \mathrm{~m} \\
\text { Jarak horizontal } & =36.566 \mathrm{~m} \\
\text { Gradien } & =(8.00 / 36.566) \times 100 \% \\
& =0.022 \%
\end{array}
$$

* maka diperoleh gradien sungai sebesar $0.022 \%$.

3. Menghitung tingkat percabangan sungai, contoh untuk sungai orde 1:

$\mathrm{Nu}$ (jumlah alur sungai untuk orde 1)

$$
=108 \text { alur sungai. }
$$

$\mathrm{Nu}+1$ (jumlah alur sungai untuk orde $1+1$ )

$$
=109
$$

Tingkat percabangan sungai $=R b=\mathrm{Nu} / \mathrm{Nu}+1$

$$
\begin{aligned}
& =108 / 109 \\
& =0,99
\end{aligned}
$$

Tabel 2 berikut memperlihatkan tingkat percabangan orde sungai untuk semua orde sungai.

TABEL III

Tingkat Orde Sungai Martapura

\begin{tabular}{|c|c|c|c|}
\hline Tingkatan & $\mathrm{Nu}$ & $\mathrm{Nu}+1$ & $\mathrm{Rb}$ \\
\hline 1 & 108 & 109 & 0.99 \\
\hline 2 & 30 & 31 & 0.97 \\
\hline 3 & 16 & 17 & 0.94 \\
\hline 4 & 7 & 8 & 0.88 \\
\hline 5 & 2 & 3 & 0.67 \\
\hline 6 & 2 & 3 & 0.67 \\
\hline 7 & 1 & 2 & 0.5 \\
\hline 8 & 1 & 2 & 0.5 \\
\hline 9 & 1 & 2 & 0.5 \\
\hline 10 & 1 & 2 & 0.5 \\
\hline
\end{tabular}

(sumber: Hasil Analisis Laboratorium PJ dan SIG Politeknik Negeri

Banjarmasin)

\section{Keterangan :}

$\mathrm{Rb} \quad=$ Indeks tingkat percabangan sungai

$\mathrm{Nu}=$ Jumlah alur sungai untuk orde ke $\mathrm{u}$

$\mathrm{Nu}+1$ = Jumlah alur sungai untuk orde ke $\mathrm{u}+1$

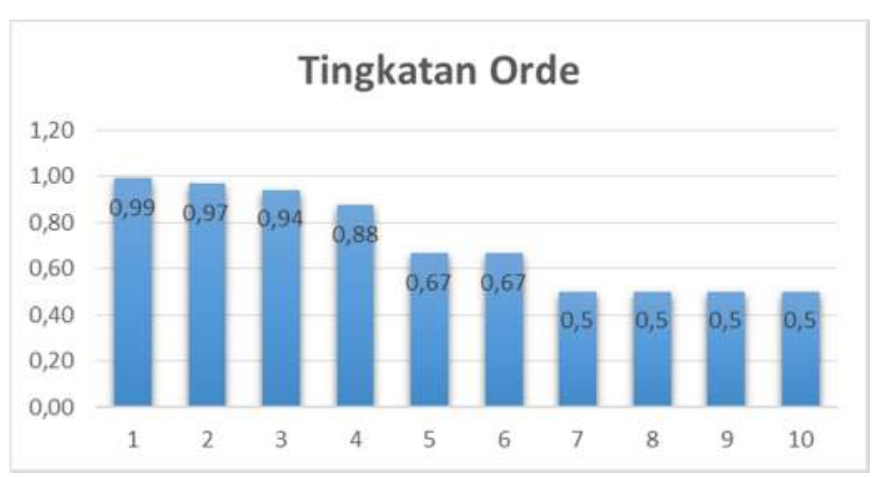

Gambar 6. Grafik Tingkatan Orde Sungai Martapura.

1. Tingkat kerapatan sungai.

Jumlah panjang sungai termasuk anak-anak sungainya $=$ $375,91 \mathrm{~km}$

Luas DAS=453,88 $\mathrm{km}^{2}$

Tingkat kerapatan sungai $=$ $=\frac{375,91}{453,88}=0,828 \mathrm{~km} / \mathrm{km}^{2}$

Tingkat kerapatan sungai sebesar $0,828 \mathrm{~km} / \mathrm{km}^{2}$ yaitu, kelas kerapatan yang sedang, dengan kata lain alur sungai melewati batuan dengan resistensi (hambatan) yang lebih lunak, sehingga angkutan sedimen yang tersangkut aliran akan lebih besar.

2. Pola sungai pada DAS Martapura adalah pola rektangular, dicirikan oleh induk sungainya memiliki kelokan-kelokan $\pm 90^{\circ}$, arah anak-anak sungai (tributary) terhadap sungai induknya berpotongan tegak lurus.

3. DAS Martapura adalah jenis DAS yang berbentuk paralel yang tersusun dari percabangan dua sub-DAS maupun sungai yang cukup besar di bagian hulu, tetapi menyatu di bagian hilirnya.

\section{KESIMPULAN}

Berdasarkan hasil dan pembahasan dapat diambil kesimpulan sebagai berikut:

1. Arcgis dan Global Mapper, dapat dimanfaatkan untuk menghasilkan peta dan sistem informasi guna menidentifikasi morfometri DAS Martapura.

2. Identifikasi morfometri DAS Martapura dapat digunakan untuk analisis dalam rangka perencanaan dan monitoring keadaan DAS Martapura beserta sungai-nya serta tindakan pengelolaan-nya.

3. DAS Martapura mempunyai luas $453,88 \mathrm{~km} 2$ dengan sungai utama yang panjangnya mencapai $36.566 \mathrm{~m}$, beda tinggi dari hulu ke hilir adalah $8.00 \mathrm{~m}$, kemiringan (gradien) sungai sebesar $0.022 \%$. Tingkat kerapatan sungai pada DAS Martapura yaitu $0,828 \mathrm{~km} / \mathrm{km} 2$. Tingkatan orde sungai adalah mencapai 10 tingkatan orde. Pola sungai pada DAS Martapura adalah pola rektangular dengan jenis DAS yang berbentuk paralel.

\section{UCAPAN TERIMA KASIH}

Sujud syukur kehadirat Allah maha pencipta atas limpahan karunia-Nya, penelitian ini dapat terselesaikan dengan baik. 
Penulis menyampaikan rasa terima kasih serta apresiasi kepada Direktur Politeknik Negeri Banjarmasin beserta jajaran Unit P3M yang telah memberikan kesempatan melakukan penelitian, kepada Ketua Jurusan Teknik Sipil beserta para dosen senior yang memberikan arahan dan bimbingan ilmiah selama ini, kepada jajaran pengelola Laboratorium PJ dan SIG, dan kepada bapak Faris Ade Irawan serta saudara Agus Salim yang telah memberikan kontribusi besar dalam proses penelitian ini. Semoga hasil karya ini bermanfaat bagi banyak pihak.

\section{REFERENSI}

Anshari Muhammad, 2011, Identifikasi Morfometri DAS Barabai, Program studi Politeknik Negeri Banjarmasin.

Asdak C. 2002. Hidrologi dan Pengelolaan Daerah Aliran Sungai. Yogyakarta: Gadjah Mada University Press.

Aqdhianti, 2015, Morfometri Daerah Aliran Sungai,http://aqdhianti.blogspot.co.id/2012/03/morfometr i-daerah-aliran sungai.html. diakses 13 Maret 2017.

Denny Charter, Irma Agtrisari, Desain dan Aplikasi GIS, Geographic Information System, 2003. Jakarta. P.T. Gramedia.

Edy Prahasta, 2005. Sistem Informasi Geografis. Edisi Revisi, Hallaf, H.P, 2005, Geomorfologi Sungai dan Pantai, Jurusan geografi FMIPA UNM.Makasar.

Linsley RK, Kohler MA, Paulhus JLH. 1982. Hidrologi Untuk Insinyur. Hermawan.

Prahasta, Eddy. 2004. Sistem Informasi Geografis: Tools dan Plug-Ins. CV. Informatika. Bandung

Soewarno, 1991. Hidrologi: Pengukuran dan Pengolahan Data Aliran Sungai (Hidrometri). Nova.Bandung

Y, penerjemah; Sianipar Y, Haryadi E, editor. Jakarta: Penerbit Erlangga. Terjemahan dari: Hydrology for Engieneers. 